\title{
$\frac{100}{\mathrm{LuT}} \mathrm{RPES}$
}

\section{PODMIOTOWOŚĆ KOMITETU OBYWATELSKIEJ INICJATYWY UCHWAŁODAWCZEJ W GMINIE}

\section{WSTĘP}

Wskutek nowelizacji ustawy z 8 marca 1990 r. o samorzązie gminnym grupie mieszkańców gminy przyznano na mocy ustawy prawo do wnoszenia obywatelskiej inicjatywy uchwałodawczej do organu stanowiącego ${ }^{1}$. Niemniej kwestia możliwości składania przez mieszkańców projektów uchwał do rady gminy ${ }^{2}$ była przedmiotem dociekań doktryny jeszcze przed jej uregulowaniem wprost na poziomie ustawowym. W piśmiennictwie wskazywano, że takie uprawnienie mogło być przyznawane $\mathrm{w}$ konkretnych gminach dzięki szerokiej samodzielności jednostek samorządu terytorialnego do kształtowania ich wewnętrznego ustroju ${ }^{3}$. Jeżeli zatem statut gminy dopuszczał składanie przez mieszkańców projektów uchwał, uznawano to za jak najbardziej zgodne z Konstytucją $R^{4}$ i ustawą z 8 marca 1990 r. o samorządzie gminnym ${ }^{5}$. Możliwość taka była wykorzystywana w praktyce przez organy stanowiące gmin ${ }^{6}$. W obowiązującym stanie prawnym art. 41a ust. 1 u.s.g. stanowi, iż grupa mieszkań-

* Beniamin Rozczyński, Uniwersytet im. Adama Mickiewicza w Poznaniu, beniamin.rozczynski@amu.edu.pl, https://orcid.org/0000-0003-2019-7923

** Adrian Misiejko, Uniwersytet im. Adama Mickiewicza w Poznaniu, misiejko.a@gmail.com, https://orcid.org/0000-0002-4949-465X

1 Ustawa z 11 stycznia 2018 r. o zmianie niektórych ustaw w celu zwiększenia udziału obywateli w procesie wybierania, funkcjonowania i kontrolowania niektórych organów publicznych, Dz. U. poz. 130.

2 Dalej jako: rada.

3 Izdebski (2014): 163-168; Uziębło (2011): 56-62; Miruć (2010): 32-33; por. Kuśnierz-Chmiel (2016): 65-67.

${ }_{4}$ Konstytucja Rzeczypospolitej Polskiej z 2 kwietnia 1997 r., Dz. U. 1997, Nr 78, poz. 483 ze zm. (dalej jako: Konstytucja RP).

5 Ustawa z 8 marca 1990 r. o samorządzie gminnym, t.jedn.: Dz. U. 2020, poz. 713 ze zm. (dalej jako: u.s.g.).

6 Zob. np. Czerw (2016): 200-212. 
ców gminy, posiadających czynne prawa wyborcze do organu stanowiącego, może wystapić z obywatelską inicjatywą uchwałodawcza. Zgodnie z art. 41a ust. 2 u.s.g. owa grupa musi liczyć:

1) w gminie do 5000 mieszkańców - co najmniej 100 osób;

2) w gminie do 20000 mieszkańców - co najmniej 200 osób;

3) w gminie powyżej 20000 mieszkańców - co najmniej 300 osób.

$\mathrm{W}$ dalszych przepisach pojawia się natomiast instytucja „komitetu inicjatywy obywatelskiej" ' Zgodnie z art. 41a ust. 4 u.s.g. komitet ma prawo wskazywać osoby uprawnione do reprezentowania komitetu podczas prac rady. Natomiast w art. 41a ust. 5 u.s.g., wśród obligatoryjnych elementów uchwały rady (związanych z obywatelska inicjatywą uchwałodawcza) znajdują się zasady tworzenia owych komitetów. Nad wyraz ograniczona regulacja dotyczaca tych konstrukcji prawnych może budzić liczne wątpliwości teoretyczne i praktyczne.

Przedmiotem niniejszego opracowania jest analiza wskazanych regulacji, celem zaś - ustalenie charakteru prawnego komitetu inicjatywy lokalnej (w szczególności ustalenie, czy dysponuje on podmiotowością na gruncie prawa cywilnego lub administracyjnego). Aktualnie brak opracowań naukowych, które poruszałyby kwestię komitetów w sposób wyczerpujący ${ }^{8}$. Dla osiagnięcia założonego celu zastosowana została metoda dogmatycznoprawna ${ }^{9}$. Pomocniczo wykorzystano orzecznictwo sądów administracyjnych oraz literaturę prawnicza. Celem utrzymania spójności wywodu analiza dotyczy przepisów u.s.g. jako regulującej ustrój podstawowej jednostki samorządu terytorialnego ${ }^{10}$.

Już na wstępie warto zaznaczyć, iż przed wprowadzeniem obowiązującej regulacji Sejm odrzucił inny poselski projekt ustawy, którego przedmiotem była wyłacznie inicjatywa uchwałodawcza w gminie, powiecie i województwie ${ }^{11}$. Dla osiagnięcia postawionych celów badawczych zasadne wydaje się zatem dokonanie analizy porównawczej co najmniej między owym projektem a obowiązująca regulacja.

\section{INSTYTUCJE ZBLIŻONE DO KOMITETU}

Ustawodawca bardzo zdawkowo uregulował instytucję komitetu inicjatywy uchwałodawczej. Konieczne wydaje się odniesienie do innych kon-

${ }^{7}$ Dalej jako: komitet.

${ }^{8}$ Co nie oznacza, że nie są one poruszane w opracowaniach poradnikowych, np. Podgórska-Rykała (2020).

${ }^{9}$ Przyjmując założenia metodologiczne teorii (koncepcji) derywacyjnej - por. Zieliński (2017).

${ }_{10}$ Analogiczne rozwiązania zostały przewidziane również w art. 42a ustawy z 5 czerwca 1998 r. o samorządzie powiatowym (Dz. U. 2020, poz. 920) oraz ustawy z 5 czerwca 1998 r. o samorządzie województwa (Dz. U. 2020, poz. 1668). Ustalenia poczynione w artykule będą punktem odniesienia w przypadku analizy ww. przepisów. Wstępnie można postawić hipotezę, że zwłaszcza w zakresie podmiotowości komitetu i jego zdolności sądowej wyniki nie będą się różnić.

${ }^{11}$ Poselski projekt ustawy o zmianie ustawy o samorządzie gminnym oraz niektórych innych ustaw, druk nr 1500, Sejm VIII kadencji, <www.orka.sejm.gov.pl> [dostęp: 17.08.2018]. 
strukcji prawnych związanych z uprawnieniami mieszkańców do partycypacji politycznej.

W pierwszej kolejności zasadne jest przywołanie wspomnianego już poselskiego projektu ustawy o zmianie ustawy o samorządzie gminnym oraz niektórych innych ustaw. Komitetowi inicjatywy uchwałodawczej miał być poświęcony projektowany art. 42b u.s.g. Miał być on tworzony przez grupę przynajmniej 3 mieszkańców gminy (mających prawo do wybierania do rady), którzy złożyliby pisemne oświadczenie o przystapieniu do komitetu. W imieniu tego ostatniego miał występować pełnomocnik lub zastępca pełnomocnika. Komitet miał wykonywać czynności związane z przygotowaniem projektu uchwały, „jej rozpowszechnieniem”"12, kampanią promocyjna, a także organizacją zbierania podpisów mieszkańców gminy popierajacych projekt. Miał on również pokrywać wydatki związane z wykonywaniem inicjatywy uchwałodawczej. Projekt nie rozstrzygał natomiast wprost kwestii podmiotowości komitetu, w szczególności nie określał jego osobowości prawnej.

W obowiązującym stanie prawnym, ze względu na przedmiot działania, najbardziej zbliżona do omawianej instytucji są komitety inicjatywy ustawodawczej, regulowane przepisami ustawy z 24 czerwca 1999 r. o wykonywaniu inicjatywy ustawodawczej przez obywateli ${ }^{13}$. Podobieństwa wydaje się również sugerować terminologia, jaka posługuje się ustawodawca ${ }^{14}$. Komitet inicjatywy ustawodawczej tworzony jest przez grupę co najmniej 15 obywateli, którzy mają prawo wybierania do Sejmu i złożyli pisemne oświadczenie o przystapieniu do komitetu ${ }^{15}$. Uzyskuje on osobowość prawną z chwilą otrzymania przez Marszałka Sejmu zawiadomienia o utworzeniu komitetu ${ }^{16}$. Komitet inicjatywy ustawodawczej wykonuje czynności związane z przygotowaniem projektu ustawy, jego rozpowszechnianiem, kampanią promocyjną, a także organizacja zbierania podpisów obywateli popierajacych projekt ${ }^{17}$. W jego imieniu i na jego rzecz działa pełnomocnik komitetu lub jego zastępca (wskazani w pisemnym oświadczeniu pierwszych 15 osób tworzacych komitet) ${ }^{18}$. Komitet pokrywa wydatki związane z wykonywaniem inicjatywy ustawodawczej i w związanych z tym celach może prowadzić zbiórki publiczne (przewidziano ponadto katalog źródeł i podmiotów, które nie mogą finansować komitetu) ${ }^{19}$. Określono również zasady rozwiązywania komitetów ${ }^{20}$.

12 Tak projekt ustawy, choć wydaje się, że chodziło raczej o rozpowszechnianie projektu uchwały (ewentualnie o rozpowszechnianie inicjatywy uchwałodawczej).

${ }^{13}$ Dz. U. Nr 62, poz. 688 (dalej jako: u.w.i.u.o.).

${ }_{14} \mathrm{~Np}$. inicjatywa ustawodawcza wykonywana przez obywateli - obywatelska inicjatywa uchwałodawcza; komitet inicjatywy ustawodawczej - komitet inicjatywy uchwałodawczej; np. art. 14 u.w.i.u.o. stanowi o reprezentowaniu komitetu inicjatywy ustawodawczej, a art. 41a ust. 3 u.s.g. o możliwości reprezentowania komitetu inicjatywy uchwałodawczej.

15 Art. 5 ust. 2 u.w.i.u.o.

16 Art. 5 ust. 4 u.w.i.u.o.

17 Art. 5 ust. 1 u.w.i.u.o.

18 Art. 5 ust. 3 u.w.i.u.o.

19 Art. 15 i 16 u.w.i.u.o. W szczególności na wykonywanie prawa inicjatywy ustawodawczej komitetowi nie mogą być przekazywane środki z budżetu państwa oraz z budżetów j.s.t.

${ }^{20}$ Art. 18 w zw. z art. 10 ust. 2 w zw. z art. 7 ust. 1 w zw. z art. 6 ust. 5 u.w.i.u.o. 
Ostatnią instytucją prawna, która wydaje się wykazywać pewne podobieństwa do komitetu inicjatywy uchwałodawczej (jeżeli chodzi o zrzeszenie nakierowane na osiagnięcie konkretnego celu związanego z partycypacją polityczna), jest komitet wyborczy. Zgodnie z art. $84 \S 1$ Kodeksu wyborczego ${ }^{21}$ prawo zgłaszania kandydatów w wyborach przysługuje komitetom wyborczym. Komitety wyborcze wykonują również inne czynności wyborcze, a w szczególności prowadzą na zasadzie wyłączności kampanię wyborczą na rzecz kandydatów. $\mathrm{Z}$ art. $84 \S 2-4$ Kodeksu wyborczego wynika natomiast, że komitety wyborcze moga być tworzone - zależnie od rodzaju wyborów - przez partie polityczne i ich koalicje, wyborców lub stowarzyszenia i organizacje społeczne. Moga w szczególności prowadzić kampanię wyborczą oraz gospodarkę finansowa, działając przez pełnomocników ${ }^{22}$. Nie są jednak osobami prawnymi, a wątpliwości budzi również kwestia przyznania im zdolności prawnej ${ }^{23}$.

Dokonana analiza pozwala na stwierdzenie, że odrzucony projekt poselski przewidywał instytucję komitetów inicjatywy uchwałodawczej częściowo na wzór komitetów inicjatywy ustawodawczej. Mając na uwadze, że komitety inicjatywy uchwałodawczej nie miały być wyposażone w osobowość prawna, można uznać je za uproszczoną i ograniczoną wersję swych pierwowzorów. Należy również stwierdzić, iż regulacja zaproponowana w projekcie ustawy była o wiele bardziej rozbudowana i rozstrzygała przynajmniej niektóre zagadnienia funkcjonowania tych podmiotów, do których nie odnosi się obowiąująca regulacja.

\section{PODMIOTOWOŚĆ PRAWNA I ZAKRES DZIALANIA KOMITETU}

Ustawa o samorządzie gminnym nie przewiduje wprost przyznania osobowości prawnej komitetom. Wydaje się, że nie może to nastapić również przez rozstrzygnięcie rady. Abstrahując bowiem od kwestii dopuszczalności przyznania osobowości prawnej w drodze aktu prawa miejscowego ${ }^{24}$, to nawet zakładając taką możliwość, tak istotny skutek powinien zostać wyraźnie przewidziany w przepisie upoważniającym ${ }^{25}$. Samo stwierdzenie ustawodawcy, że

\footnotetext{
${ }^{21}$ Ustawa z 5 stycznia 2011 r. - Kodeks wyborczy, Dz. U. 2019, poz. 684 ze zm. (dalej jako: Kodeks wyborczy).

${ }^{22}$ Czakowska, Raźny (2011): 3.

${ }^{23}$ Banaszak (2015); Czakowska, Raźny (2011: 81) wyrazili pogląd, że komitetom wyborczym nie można przypisać zdolności prawnej w rozumieniu prawa cywilnego, lecz jedynie podmiotowość administracyjnoprawną. Warto zauważyć, iż w odpowiedzi na zapytanie poselskie nr 8465 z 23 lipca 2015 r. podsekretarz stanu w Ministerstwie Finansów stwierdził, że komitety wyborcze tworzone przez organizacje społeczne, stowarzyszenia i wyborców sa jednostkami organizacyjnymi nieposiadającymi osobowości prawnej, do których stosuje się przepisy o podatku dochodowym od osób prawnych (nie są nimi natomiast komitety wyborcze partii politycznych i ich koalicji).

${ }^{24}$ Sobolewski (2017) stwierdza, że „przepisem prawa” w rozumieniu art. 33 k.c. może być również przepis aktu prawa miejscowego. Odmiennie Górczyński (2018), który stoi na stanowisku, że niedopuszczalne jest regulowanie tej kwestii przez akt podstawowy.

${ }^{25}$ Jak wskazuje Szczepaniak (2016): „[...] normatywna koncepcja osób prawnych sprowadza się do wymogu istnienia przepisu, w którego treści dana jednostka została expressis verbis wypo-
} 
rada może ustanowić zasady tworzenia komitetów, jest z pewnością niewystarczające do wywodzenia tak daleko idących skutków prawnych.

Sprawa komplikuje się w przypadku ustalenia, czy komitetom można przyznać w drodze aktu prawa miejscowego zdolność prawną (a więc zdolność do nabywania praw i zaciagania zobowiązań) w rozumieniu k.c. ${ }^{26}$ Jak bowiem wskazuje się w piśmiennictwie, nie musi być ona przyznana wprost, lecz może wynikać z całokształtu regulacji odnoszących się do danego podmiotu ${ }^{27}$. Skoro jednak ustawodawca nie wypowiada się w przedmiocie zdolności prawnej, zasadna wydaje się analiza zakresu działania komitetu. Nie jest bowiem wykluczone, że - ze względu na ograniczone uregulowanie kwestii związanych z komitetem - to właśnie przedmiot działania danej jednostki może przesądzić o posiadaniu owej zdolności.

Ustawa nie reguluje wprost działań, jakie może podejmować komitet. Stanowi jedynie, że może być on reprezentowany podczas prac rady. Jak już wskazano, zgodnie z odrzuconym projektem poselskim kwestie te miały być uregulowane wprost w ustawie i obejmować: przygotowanie projektu uchwały, jej rozpowszechnienie, kampanię promocyjną oraz organizację zbierania podpisów mieszkańców gminy popierajacych projekt. Komitet miał również pokrywać wydatki związane z wykonywaniem inicjatywy. W obowiązujacym stanie prawnym z ustawy wprost wynika jedynie, iż komitet wyznacza reprezentantów do uczestnictwa w pracach rady.

Ustawa o samorządzie gminnym nie stanowi wprost nawet o tak elementarnych kwestiach, jak to, czy utworzenie komitetu jest pierwotne względem zbierania podpisów, czy może odwrotnie - to podpisujący się mieszkańcy stanowią komitet (skoro to im, zgodnie z art. $41 \mathrm{a}$ ust. $1 \mathrm{w}$ zw. z ust. 2 u.s.g., przysługuje inicjatywa uchwałodawcza). Właściwa wykładnia możliwa jest w związku z przepisami u.w.i.u.o. ${ }^{28}$ Komitet jest zatem pierwotnie tworzony przez grupę osób (określoną w procedurze ustanowionej przez radę). Zadaniem członków komitetu lub samego komitetu jest zebranie podpisów takiej grupy mieszkańców, którym w danej gminie przysługuje inicjatywa uchwałodawcza. Następnie (również zgodnie z zasadami ustalonymi przez radę) członkowie komitetu lub sam komitet przedstawia zebrane podpisy ${ }^{29}$. Komitet może za-

sażona w »osobowość prawnąu lub nazwana "osobą prawną«". W doktrynie stwierdzono również, iż osobowość prawna nie może być stwierdzona w drodze wykładni rozszerzającej - Sobolewski (2017); Frąckowiak (2012): 1140. Wydaje się zatem, ż niedopuszczalne byłoby również zastosowanie wykładni rozszerzającej przy analizie przepisów kompetencyjnych do wydania aktów prawa miejscowego.

${ }^{26}$ Ustawa z 23 kwietnia 1964 r. - Kodeks cywilny, t.jedn.: Dz. U. 2019, poz. 1145 ze zm. (dalej jako: k.c.).

27, ,...] zdolność prawna wynika pośrednio z przepisów regulujących funkcjonowanie danej jednostki organizacyjnych" - Szczepaniak (2017); podobnie Sobolewski (2017). Bardziej restrykcyjne stanowisko prezentuje Frackowiak (2012): 1210-1212.

${ }^{28}$ Wydaje się, że rozwiązaniem umożliwiającym utrzymanie założenia o racjonalnym prawodawcy byłoby przyjęcie, iż uznał on za dopuszczalne stosowanie analogii do uprzedniej ustawy (u.w.i.u.o.) i w tym celu ograniczył szczegółowość regulacji art. 41a u.s.g.

${ }_{29}$ Tej drugiej ewentualności nie zakwestionował np. NSA w wyroku z 22 listopada 2019 r., I OSK 1410/19, CBOSA. 
tem pełnić funkcję pośrednika między mieszkańcami korzystającymi ze swego uprawnienia a organem gminy. Należy jednak podkreślić, że w obowiązującym stanie prawnym nie można wymusić na radzie uregulowanie w sposób analogiczny do tej przewidzianej przepisami u.w.i.u.o. ${ }^{30}$

Ustawodawca nie przewidział szczegółowych wytycznych dla rady w zakresie stanowienia aktów prawa miejscowego na podstawie kompetencji wynikajacych $\mathrm{z}$ art. 41 ust. 5 u.s.g. W konsekwencji pozostawił organowi stanowiącemu dość dużą swobodę działania. Powstaje pytanie, czy rada może kształtować zakres działania komitetów. Odpowiedź jest tylko częściowo pozytywna i wymaga poczynienia pewnych zastrzeżeń.

Jak wynika $\mathrm{z}$ art. $41 \mathrm{a}$ ust. 5 u.s.g., rada nie otrzymała kompetencji do stanowienia o zasadach uczestniczenia komitetu w pracach nad projektem uchwały. Wydaje się jednak, że kwestia wykonywania inicjatywy uchwałodawczej mieszkańców może być zaliczona do zagadnień ustroju wewnętrznego jednostek samorządu terytorialnego (j.s.t.). W konsekwencji wydaje się, iż miejscem, w którym można uregulować zasady, na jakich przedstawiciel komitetu uchwałodawczego może uczestniczyć w pracach rady i jej komisji, jest statut gminy. Mając jednak na uwadze brzmienie art. 41a ust. 4 u.s.g., należy stwierdzić, że ustalenie owych zasad nie może skutkować w praktyce ograniczeniem realizacji prawa do reprezentacji. Co więcej, użycie sformułowania „podczas prac rady gminy” należy rozumieć szeroko. Nie może to oznaczać jedynie możliwości wygłaszania stanowisk na sesjach rady, ale również musi obejmować uprawnienie do aktywnego uczestnictwach w pracach komisji rady. „Prace” rady różnią się bowiem od węższego pojęcia „sesji”. W sytuacji, w której ustawa przewiduje uprawnienia mieszkańców odnośnie do partycypacji, niedopuszczalne wydaje się stosowanie wykładni zawężającej wbrew literalnemu brzmieniu przepisu.

W odniesieniu do ustalania zasad promocji obywatelskich inicjatyw uchwałodawczych wydaje się, że rada może przewidzieć na przykład przyznanie uprawnienia do wskazania przez komitet materiałów promocyjnych, które miałyby zostać umieszczone na wskazanych przez gminę elementach jej infrastruktury. Aby jednak komitet mógł w znaczeniu cywilnoprawnym dysponować jakimikolwiek materiałami promocyjnymi, musiałby posiadać przynajmniej zdolność prawną i zdolność do czynności prawnych. Trudno zakładać, by z ogólnego w brzmieniu przepisu upoważniającego można by wyprowadzić dopuszczalność ustalania takiego zakresu działania komitetu, który wymagałby możności dysponowania jakimkolwiek mieniem i w konsekwencji wymuszałby uznanie, że dysponuje on zdolnością prawną. Niedopuszczalna wydaje się również sytuacja, gdy - przy braku jednoznacznego rozstrzygnięcia przez ustawodawcę - niektóre komitety miałyby dysponować zdolnością prawną (gdy rada odpowiednio szeroko określiłaby ich zakres działania), a inne nie. Nie można wykluczyć natomiast przyznania pewnych administracyjnoprawnych

${ }^{30}$ Nie można jednoznacznie wykluczyć dopuszczalności uchwalenia takiej procedury, która będzie zakładać, że komitet zostanie powołany dopiero po złożeniu projektu uchwały przez mieszkańców, którzy zebrali podpisy pod projektem. Skoro prawodawca pozostawił radzie samodzielność w tym zakresie, to analogie należy wyprowadzać pomocniczo. 
kompetencji do korzystania z mienia gminy (np. tablic ogłoszeń lub w zakresie zgłaszania materiałów do publikowania w BIP), ale i wówczas trudno ustalić, w jaki sposób komitet - bez jasno określonych organów - miałby móc korzystać z owych uprawnień.

W konsekwencji należy uznać, że zakres działania komitetu jest bardzo ograniczony. Wynika on zasadniczo z ustawy i obejmuje uczestnictwo w pracach organu stanowiacego (w tym wskazanie osób reprezentujacych komitet). Niewykluczone jest również określenie, że do zakresu działania komitetu należy zbieranie podpisów mieszkańców pod projektem oraz wniesienie projektu do rady (z zastrzeżeniem omówionych dalej wątpliwości co do organu, który miałby działać za komitet). Należy przy tym wskazać, że możliwość odwoływania się do przepisów u.w.i.u.o. celem ustalenia zakresu działania komitetu jest istotnie ograniczona i musi następować bardzo ostrożnie ze względu na brak wyraźnego przyznania mu podmiotowości prywatnoprawnej ${ }^{31}$. Oznacza to w szczególności, iż nie może on gromadzić środków finansowych ani wydatkować ich na przykład na promocję danej inicjatywy. Z drugiej strony należy wskazać, iż w skrajnych przypadkach może nastapić takie sformułowanie uchwał wydanych na podstawie art. $41 \mathrm{a}$ ust. 5 u.s.g., że zewnętrzny przedmiot działania komitetu zostanie ograniczony do absolutnego minimum (wynikającego bezpośrednio z u.s.g. i natury rzeczy - złożenia projektu i możliwości uczestnictwa w pracach rady ${ }^{32}$ ).

Ustalony powyżej zakres działania komitetu pozwala jednak na wysnucie tezy, iż przysługuje mu daleko ograniczona podmiotowość administracyjnoprawna $^{33}$. Jak wskazano w piśmiennictwie, jej zakres wynika z przepisów prawa (przepisy nie stanowią bowiem wprost o nadaniu podmiotowości w zakresie prawa administracyjnego ${ }^{34}$. W analizowanym przypadku owa podmiotowość

31 Wydaje się, że choć podmiotowość prywatnoprawna może wynikać z przepisów o funkcjonowaniu danej struktury, to niedopuszczalna jest wykładnia rozszerzająca, która pozwalałaby na taką interpretacje przepisów art. 41 a ust. 5 u.s.g., by owa podmiotowość wynikała właśnie z nich. Jedynie w przypadku wyraźnego przyznania komitetowi zdolności prawnej można by zastanawiać się, czy akty prawa miejscowego mogą rozszerzać jego przedmiot działania o czynności związane np. z korzystaniem z mienia gminy celem promocji inicjatywy.

32 Z zastrzeżeniem uwag poczynionych w odniesieniu do samodzielności prawotwórczej rady.

33 Jak wskazał Niczyporuk (2018: 239), celem instytucji organu administracji publicznej jest zabezpieczenie reprezentacji podmiotowi administracji publicznej. „Ta koncepcja prawnicza bazuje na teorii reprezentacji, gdyż dokonywanie czynności prawnych przypisuje się tutaj reprezentowani - organowi administracji publicznej, aczkolwiek z jego woli wynikają bezpośrednio skutki prawne dla reprezentowanego podmiotu administracji publicznej”. Rozważania należy odnosić do kwestii komitetu tylko o tyle, o ile stanowią one w sposób ogólny o relacji między organem a podmiotem istniejącym na gruncie prawa administracyjnego (tym bardziej że jego aktywność skupia się na sferze ustrojowo-kompetencyjnej w relacji z organem stanowiącym gminy). Wydaje się, że komitet nie jest organem - nie ma bowiem podmiotu zbiorowego, który miałby reprezentować. Grupa obywateli występująca z inicjatywą uchwałodawczą nie stanowi bowiem podmiotu korporacyjnego, dla którego organem mógłby być komitet, lecz niezorganizowany zbiór podmiotów. Komitet może być natomiast traktowany jako swoista (bardzo ograniczona) korporacja mieszkańców tworzących go zgodnie z odpowiednią uchwałą rady gminy, służąca realizacji zgodnego z prawem celu; por. Kopaczyńska-Pieczniak (2019): 27-84.

34 Niczyporuk (2016): 52-53. Autor wskazuje, że „[...] minimalny wymóg uznania prawnej relewantności jednostek organizacyjnych stanowi objęcie ich regulacją prawna, która zalicza się do prawa administracyjnego" (ibid.: 190). 
jest ściśle związana z celem komitetu, a więc realizacja prawa do inicjatywy uchwałodawczej obywateli. Jest to uczestnictwo w wykonywaniu zadań publicznych. W takim zakresie jest lub może być podmiotem pewnych uprawnień i obowiązków (o charakterze administracyjnoprawnym), które mogą wynikać także z aktów prawa miejscowego. Wydaje się zatem, że komitet jest podmiotem swoistego stosunku administracyjnego o trudnym do ustalenia charakterze, którego drugą strona jest gmina ${ }^{35}$.

\section{REPREZENTOWANIE KOMITETU}

Mogłoby się wydawać, że komitet nie ma organów w ścisłym tego słowa znaczeniu. Może wskazywać osoby uprawnione do reprezentowania go podczas prac rady - „reprezentantów”. Jest to co najwyżej specyficzny rodzaj pełnomocnika. Wojewódzki Sąd Administracyjny w Gdańsku w wyroku z 4 lipca 2019 r. stwierdził, że niedopuszczalne jest takie skonstruowanie uchwały $\mathrm{z}$ art. $41 \mathrm{a}$ ust. 5 u.s.g., by wynikał z niej obowiązek wyłonienia reprezentan$\mathrm{ta}^{36}$. Wydaje się, że nie jest to równoznaczne $\mathrm{z}$ zakazem wprowadzenia obowiązku wskazania odrębnego pełnomocnika, który dokonywałby czynności wymaganych uchwała na poczatkowym etapie funkcjonowania komitetu. Jak bowiem wskazał NSA, organ stanowiący może nakazać komitetowi wskazanie swojego pełnomocnika (odrębnego od reprezentanta) do czynności związanych ze zgłaszaniem projektu (np. w zakresie uzupełnienia braków formalnych) ${ }^{37}$. Dyskusyjne jest przy tym przyjęcia, że rada jest uprawniona do nakładania w drodze uchwały dodatkowych zadan oraz kompetencji na pełnomocnika komitetu (np. czyniąc go jedynym właściwym podmiotem do kontaktów i podejmowania wszelkich aktywności związanych z inicjatywa). Mogłoby to bowiem godzić w wolność członków komitetu ${ }^{38}$.

Ustawa nie określa jednak, w jaki sposób komitet może wskazać osoby uprawnione do swego reprezentowania. Wydaje się zatem, iż rada jest obowiazana do określenia $\mathrm{w}$ uchwale $\mathrm{z}$ art. $41 \mathrm{a}$ ust. 5 u.s.g. takich zasad tworzenia komitetów, które będą wymagać podania przez zgłaszających sposobu wyłaniania reprezentantów lub pełnomocników. Bez tej regulacji mogłoby dojść do paraliżu działania komitet. Kompleksowe rozstrzygnięcie tego zagadnienia

${ }^{35} \mathrm{Z}$ jednej strony można rozważać, czy nie jest to stosunek administracyjny ustrojowy (wynikający z przynależności wnoszenia projektu uchwały jako elementy spraw korporacyjnych gminy), z drugiej zaś - trudno zignorować aspekt materialny tego stosunku (wynikający z wprost uregulowanych w ustawie uprawnień mieszkańców do składania projektu uchwały). Wydaje się zatem, że ustrojowy stosunek między komitetem a gminą jest pewnym refleksem ustrojowego i materialnego stosunku administracyjnoprawnego istniejącego między gminą i członkami wspólnoty samorządowej tworzącymi komitet; por. Giętkowski (2010): 129-138.

${ }^{36}$ Wyrok WSA w Gdańsku z 4 lipca 2019 r., III SA/Gd 333/19, CBOSA.

${ }^{37}$ Wyrok NSA z 22 listopada 2019 r., I OSK 1410/19, CBOSA.

${ }^{38}$ Zob. np. rozstrzygnięcie nadzorcze nr PN.4131.385.2018 Wojewody Warmińsko-Mazurskiego z 30 października 2018 r., Dz. Urz. Woj. Warmińsko-Mazurskiego 2018, poz. 4720. 
powinno uwzględniać także możliwość zmiany „reprezentacji” (np. na wypadek śmierci uprzednio wyznaczonego).

Skoro ustawa stanowi, że to komitet wskazuje swoich reprezentantów, to niejako milcząco wynika z tego również konieczność istnienia nienazwanego wprost „organu”, który będzie mógł ich wskazać. Owym „organem” będą zatem działajacy wspólnie członkowie komitetu (na zasadach określonych w uchwale rady; uchwała nie powinna jednak regulować zasad podejmowania uchwał, lecz jedynie wymagać, by zostały one określone przy tworzeniu komitetu). Drugą sfera, w której ewentualnie mógłby działać ów „organ”, jest sfera promocji. Jak już jednak ustalono, nie oznacza to działania w sferze cywilnoprawnej, lecz co najwyżej na gruncie prawa administracyjnego.

\section{POZYCJA KOMITETU W STOSUNKU DO ORGANU STANOWIĄCEGO GMINY}

Z uwagi na szczególną rolę komitetu w procesie uchwałodawczym zasadnym jest podjęcie próby określenia pozycji badanego podmiotu w odniesieniu do pozycji rady. Choć liczne podobieństwa z komitetem inicjatywy ustawodawczej sugeruja, że oba komitety są rodzajami zrzeszeń osób fizycznych, nie można a piori wykluczyć różnic między nimi.

Przepis art. $41 \mathrm{a}$ ust. 5 u.s.g. stanowi o tym, że rada określa między innymi zasady tworzenia komitetów inicjatyw uchwałodawczych oraz zasady promocji obywatelskich inicjatyw uchwałodawczych. Biorac pod uwage przepis art. $41 \mathrm{a}$ ust. 1 u.s.g., należałoby przyjąć, że utworzenie komitetu i rozpoczęcie działalności następuje wraz z podjęciem decyzji przez grupę mieszkańców gminy (posiadających czynne prawa wyborcze do organu stanowiącego). Tym samym proces formowania się i wyodrębniania się sensu largo komitetu ma charakter dwuetapowy.

Pojawiają się wątpliwości, czy formujący się komitet wyodrębnia się systemowo i organizacyjnie w stosunku do rady sensu stricto. W związku z powyższym zasadne jest podjęcie próby wskazania kwalifikacji podmiotowej komitetu, na skutek której wyłaniają się trzy możliwości ${ }^{39}$ :

1) komitet jako szczególnego rodzaju podmiot prawa publicznego, który działa niezależnie od rady w procesie uchwałodawczym;

2) komitet jako pomocniczy podmiot prawa publicznego, którego celem jest wspieranie rady w procesie uchwałodawczym;

3) komitet jako hybrydowy podmiot prawa publicznego, którego pozycja administracyjnoprawna ulega zmianie w zależności od przedmiotu projektu uchwały.

Przepis art. 41a u.s.g. nie wskazuje jednoznacznie, czy rada ma prawo modyfikować treść wniesionego przez mieszkańców projektu uchwały. Analizując

39 Podstawa kwalifikacji jest zakres kompetencji komitetu oraz możliwości wypływania na proces uchwałodawczy. 
treść przepisu art. 41a ust. 3 u.s.g., można dojść do wniosku, że rada nie jest uprawniona do ingerencji w brzmienie przedłożonego przez komitet projektu. Wskazany przepis stanowi, iż projekt uchwały zgłoszony w ramach obywatelskiej inicjatywy uchwałodawczej (z mocy prawa) staje się przedmiotem obrad rady na najbliższej sesji po złożeniu projektu. Tym samym należy uznać, że zastosowana przez prawodawcę konstrukcja przepisu nie pozwala na ingerencję w treść wniesionego przez komitet projektu uchwały w komisjach rady, gdyż powinien on niejako automatycznie wejść pod obrady organu stanowiącego jako takiego ${ }^{40}$. Jako przykład może posłużyć proces uchwałodawczy w zakresie budżetu obywatelskiego. Warto przy tym zauważyć, że w art. 5a ust. 4 u.s.g. prawodawca jednoznacznie przesądził, iz rada w toku prac nad projektem uchwały budżetowej nie może usuwać lub zmieniać w stopniu istotnym zadań wybranych w ramach budżetu obywatelskiego. W przypadku inicjatywy uchwałodawczej analogicznego przepisu brak. Brak również jakichkolwiek regulacji, które sugerowałyby zmianę charakteru prawnego komitetu ze względu na przedmiot projektu uchwały, którą wnosi.

Należy przy tym podkreślić, że choć art. 41a ust. 4 u.s.g. uprawnia komitet do wskazania reprezentanta, który bierze udział w pracach rady, to językowa wykładnia tegoż przepisu nie pozwala na przyjęcie, że w zakres kompetencji reprezentanta wchodzi prawo do władczej ingerencji w proces stanowienia przez radę aktów prawa miejscowego. Nie jest przy tym powoływany przez radę ani wójta (lub inny organ władzy publicznej). Trudno uznać go zatem za podmiot pomocniczy względem rady. Tym samym należy uznać, że komitet stanowi szczególnego rodzaju podmiot prawa publicznego i specyficzne zrzeszenie mieszkańców, które działa niezależnie od rady w procesie uchwałodawczym.

Rada nie jest związana treścią projektu autorstwa komitetu, gdyż jest „gospodarzem” procesu uchwałodawczego oraz jedynym podmiotem kompetentnym w sprawie. W doktrynie komitet określa się jako ,jedyne źródło inspiracji organu stanowiącego" ${ }^{41}$. Jest to jednak inspiracja mająca źródło w uregulowanym wprost w ustawie prawie mieszkańców do zajmowania się sprawami ich wspólnoty samorządowej. Biorąc pod uwagę przedstawioną konstrukcję organizacyjną oraz założenie, że analizowany podmiot stanowi mechanizm społeczeństwa obywatelskiego pozwalający na bezpośredni udział obywateli w podejmowaniu rozstrzygnięć przez organ uchwałodawczy, należy podkreślić, że proces uchwałodawczy może zyskać na jakości w przypadku zachowania swoistej równowagi pomiędzy obydwoma podmiotami, ze szczególnym uwzględnieniem zaangażowania członków komitetu.

Wskazane byłoby opowiedzieć się za pierwszym rozwiązaniem. Skoro zatem to rada jest gospodarzem, a przepisy stanowią jedynie o tym, że projekt ma stać się przedmiotem obrad, trudno odmówić radzie możliwości modyfikacji projek$\mathrm{tu}^{42}$. Nie zmienia to istoty roli, jaka powierzył komitetowi prawodawca ${ }^{43}$. W pro-

${ }^{40}$ Por. Marchaj (2018), który wysuwa tezę o niedopuszczalności zmian w projekcie.

${ }^{41}$ Zob. Ziółkowski (2018) za: Uziębło (2011): 58.

${ }^{42}$ Odmiennie Banat (2020): 90.

${ }^{43}$ Rola komitetu polega na „wzmacnianiu demokratyzacji procesu prawotwórczego przy stanowieniu prawa lokalnego przez organy samorządowe”, co „ma na celu podniesieniu autorytetu 
cesie uchwałodawczym komitet działa niezależnie od rady, gdyż jego podstawowym zadaniem jest przygotowanie projektu uchwały i przedłożenie go organowi stanowiacemu. W dalszym zakresie działania podejmuje rada, która może:

1) przyjąć projekt uchwały w całości;

2) odrzucić projekt uchwały;

3) uchwalić poprawki i przyjąć zmieniony projekt.

\section{ZDOLNOŚĆ SĄDOWA KOMITETU W POSTĘPOWANIU SĄDOWOADMINISTRACYJNYM}

Powstaje zatem pytanie, czy komitetowi można przypisać zdolność sądowadministracyjną w sprawach dotyczących jego interesu prawnego. Warto również udzielić odpowiedzi, w jakim przedmiocie potencjalna skarga mogłaby zostać złożona do wojewódzkiego sądu administracyjnego.

Przepis art. $41 \mathrm{a}$ ust. 3 u.s.g. wyznacza maksymalny trzymiesięczny termin, w którym projekt złożony w ramach obywatelskiej inicjatywy uchwałodawczej powinien stać się przedmiotem obrad rady. Naruszenie tego terminu będzie kreować uprawnienie do złożenia skargi na bezczynność organu administracji publicznej (rady) ${ }^{44}$. Przepis art. 101a u.s.g. stanowi o tym, że gdy organ gminy nie wykonuje czynności nakazanych prawem albo przez podejmowane czynności prawne lub faktyczne narusza prawa osób trzecich, to wówczas każdy, czyj interes prawny lub uprawnienie zostały naruszone, może wnieść skargę do sądu administracyjnego ${ }^{45}$. Przy czym wnoszący skargę musi wykazać związek przyczynowy między bezczynnością a naruszeniem jego interesu prawnego lub uprawnienia ${ }^{46}$. Interesem prawnym w danej sprawie będzie jedynie interes indywidualny, aktualny i obiektywny, którego źródłem jest obowiąujacy przepis prawa, dający podstawę do kształtowania uprawnień lub obowiązków. Prawo podmiotowe w tym zakresie przysługuje grupie mieszkańców, która wystapiła z obywatelską inicjatywą uchwałodawczą. Pozwalałoby to przyjaćc, że skargę, o której stanowi przepis art. 101a u.s.g., mogą wnieść tylko wszyscy mieszkańcy, którzy poparli projekt uchwały (w liczbie co najmniej wymaganej

\footnotetext{
i wzrost akceptowalności tworzonego prawa. Ponadto stanowi skuteczne narzędzie ułatwiające szybką i adekwatną reakcję prawną na zmieniającą się rzeczywistość”, Banat (2020): 91.

${ }^{44} \mathrm{~W}$ ocenie Banat (2020: 91) skargi do sądów administracyjnych na bezczynność rady lub z uwagi na modyfikację przedłożonego projektu byłby odrzucane jako niedopuszczalne.

${ }^{45}$ Powyższe rozważania można również odnieść do sytuacji, w której rada nie wzięła pod uwagę złożonego projektu uchwały lub w istotny sposób dokonała jego zmian. Zdaniem Kisiela (2012: 109) zainicjowane postępowanie sądowoadministracyjne miałoby na celu ustalenie, czy zachowany został termin i inne wymogi stricte formalne, a ponadto „,czy argumentacja uzasadnienia zaskarżonej uchwały jest na tyle spójna, logiczna, poparta ustaleniami faktycznymi, że nie można zasadnie zarzucić radzie arbitralności decydowania”.

${ }^{46}$ Dla uznania bezczynności rady konieczne jest ustalenie, że była ona zobowiązana, na podstawie przepisów prawa, do podjęcia określonych czynności. Dla zasadności skargi na bezczynność nie maja znaczenia powody, z jakich działanie to zostało zaniechane (por. wyrok NSA z 31 stycznia 2017 r., I OSK 1690/15, CBOSA).
} 
przez art. 41a ust. 2 u.s.g.). Poza wskazanymi uprawnionymi podmiotami nie jest wykluczone, że skargę w zaistniałej sprawie mogłaby również wnieść indywidualnie każda osoba, która wchodzi w skład grupy występującej z obywatelska inicjatywą uchwałodawczą ${ }^{47}$. Zagadnienie to wymaga jednak odrębnego omówienia ${ }^{48}$.

Z uwagi na szczególny zakres podmiotowy i przedmiotowy komitetu o charakterze publicznym zasadne byłoby dokonanie analizy przez pryzmat cech, które predestynowałyby komitet do występowania w postępowaniu sądowoadministracyjnym jako organizacja społeczna ${ }^{49}$. Naczelny Sąd Administracyjny w uchwale z 12 grudnia 2005 r. ${ }^{50}$ podkreślił, że przepis art. 12 Konstytucji RP ustanawia otwarty zbiór podmiotów (z uwagi na różnorodne formy organizacyjne pozwalające na realizację prawa do zrzeszania się obywateli), które mogą być uznane za organizacje społeczne. Ponadto NSA wyszczególnił pięć cech wspólnych, które można uznać za minimalny zespół cech charakteryzujących organizację społeczną ${ }^{51}$ :

1) wyodrębniony zespół osób, które w sposób dobrowolny przynależą do organizacji;

2) właściwy zespół przepisów znajduje zastosowanie w zakresie określenia struktury, zakresu praw i obowiązów, organizacyjnej odrębności i samodzielności;

3) działalność i cele organizacji określone sa przede wszystkim statutem i muszą pozostawać w zgodzie z celami państwa;

4) organy organizacji pochodzą z wyborów tych, którzy organizację społeczną tworza;

5) organizacja pozostaje pod kontrolą i nadzorem organów władzy publicznej.

Biorąc pod uwagę wyżej wskazane przesłanki kwalifikujące badany podmiot jako organizację społeczna, należy dojść do wniosku, że komitet nie posiada wszystkich niezbędnych cech, które pozwalałyby na jego pozytywne zakwalifikowanie. Tym samym komitet nie posiada zdolności sądowej zgodnie z przepisem art. $25 \S 4$ p.p.s.a. ${ }^{52} \mathrm{Na}$ powyższy stan rzeczy wpływa przede wszystkim daleko idąca ograniczona zdolność organizacyjna powodowana brakiem podstaw do prawnie relewantnego określenia ustroju komitetu przez tworzace go osoby. Ponadto powstały komitet nie posiada stricte wykształconych organów, które składałyby się z jego członków wybranych w drodze wy-

${ }^{47}$ Podobnie Podgórska-Rykała (2020). Zob. również Gajewski (2018).

48 Warto przy tym wskazać na wyrok NSA z 20 października 2017 r., I OSK 1297/17, CBOSA, w którym uznano interes prawny mieszkańca wsi do zaskarżenia uchwały w przedmiocie zgody na wydzierżawienie nieruchomości stanowiącej mienie gminne w rozumieniu u.s.g.

${ }^{49} \mathrm{~W}$ rozumieniu przyjmowanym na gruncie k.p.a. i p.p.s.a. Należy jednakże zaznaczyć, że w doktrynie i orzecznictwie obowiązują różne ujęcia definiujące organizację społeczną; zob. Grossmann, Piątek (2016): 79-80.

${ }^{50}$ Uchwała NSA z 12 grudnia 2005 r., II OPS 4/05, ONSAiWSA 2006, nr 2, poz. 37.

51 Wyrok NSA z 31 stycznia 2017 r., I OSK 1690/15, CBOSA.

${ }^{52}$ Ustawa z 30 sierpnia 2002 r. - Postępowanie przed sądami administracyjnymi, t.jedn.: Dz. U. 2019, poz. 2325 (dalej jako: p.p.s.a.). 
borów ${ }^{53}$. Jak już wspomniano, art. 41a ust. 4 u.s.g. stanowi jednak o możliwości wyboru reprezentanta, natomiast - po pierwsze - wybór ten ma charakter fakultatywny, a po drugie, zakres uprawnień reprezentanta jest wskazany przez przepis ustawy, tj. do występowania w imieniu komitetu podczas prac rady ${ }^{54}$. Tym samym „reprezentant” nie mógłby reprezentować komitetu przed sądem administracyjnym i podejmować czynności w imieniu komitetu. Jeżeli natomiast wszyscy członkowie komitetu udziela pełnomocnictwa jednemu $\mathrm{z}$ nich, to będzie on reprezentował samych członków (ich indywidualny interes), a nie komitet ${ }^{55}$.

\section{PODSUMOWANIE}

Komitety są specyficznymi formami zrzeszania się obywateli w celu partycypacji w wykonywaniu zadań publicznych przez wspólnotę samorządową. Stanowia podmioty prawa administracyjnego wyłącznie w zakresie bezpośrednio związanym z wykonywaniem przez mieszkańców prawa inicjatywy uchwałodawczej. Nie posiadają zdolności ani osobowości prawnej w rozumieniu prawa cywilnego. Nie moga być im one również nadane bezpośrednio w drodze gminnego aktu prawa miejscowego lub poprzez wynikajaca z nich procedurę (choć akty te mogą wpływać na zakres działania komitetów). Komitety nie dysponują również zdolnością sądowoadministracyjną - ani ze względu na swój interes prawny, ani jako uczestnicy na prawach strony. W konsekwencji należy stwierdzić, że ich znaczenie jest znacznie mniejsze, niż przewidywał to niezrealizowany projekt poselski i dodatkowo może różnić się ze względu na lokalne uregulowania.

Uzasadnione jest zatem wysunięcie postulatów de lege ferenda. Zasadne byłoby doprecyzowanie kolejności i relacji między poszczególnymi etapami

${ }^{53}$ Dokonując analogii do regulacji dotyczących organów organizacji społecznych (w uprzednim stanie prawnym), można zauważyć, że stowarzyszenie zwykłe nie posiadało organów (zgodnie z wyrokiem NSA z 13 marca 2014 r., II OSK 2525/12, CBOSA, w szczególności organem stowarzyszenia zwykłego nie mógł być jego przedstawiciel) sensu stricto (po nowelizacji - w związku z ustawą z 25 września 2015 r. - o zmianie ustawy - Prawo o stowarzyszeniach oraz niektórych innych ustaw [Dz. U. poz. 1923], dopuszczalne jest posiadanie przez stowarzyszenie zwykłe organów w postaci zarządu oraz organu kontroli wewnętrznej), przez które mogło działać w obrocie prawnym (pro foro externo). Jak wskazali Piątek i Grossman (2016: 80-81), brak wykształconych organów przez stowarzyszenie zwykłe nie stanowiło konstytutywnej cechy organizacji społecznej. Tym samym należy dojść do wniosku, że za wystarczające do zaliczenia badanego podmiotu do kategorii organizacji społecznych można uznać posiadanie przez niego określonej struktury organizacyjnej (w zakresie stowarzyszenia zwykłego - w drodze przyjętego regulaminu). W przypadku komitetu, z uwagi na brak jednoznacznie określonej struktury organizacyjnej (np. w drodze ustawowo przewidzianego regulaminu przyjmowanego przez grupę mieszkańców uprawnioną do wniesienia projektu lub osoby inicjujące powstanie komitetu), należy uznać, iż stanowi on odrębny od rady podmiot.

${ }^{54}$ Zob. wyrok WSA w Olsztynie z 7 marca 2019 r., II SA/OI 58/19, CBOSA.

${ }^{55}$ Kwestię uznanie działających wspólnie członków komitetu za organ komitetu omówiono wyżej. 
procedury, zwłaszcza zaś: przygotowaniem projektu uchwały, powołaniem komitetu, zbieraniem podpisów (co nie wyklucza pozostawienia dużej samodzielności rady). Przyjmując, że komitet stanowi formę zorganizowania się członków wspólnoty gminnej, należy wyraźnie wskazać, że określają oni jego ustrój i moga decydować o jego zmianie. Podmioty inicjujące utworzenie komitetu powinny określić regulamin jego funkcjonowania (np. poprzez załączenie go w ramach wniosku o utworzenie komitetu). Powinny znaleźć się w nim postanowienia dotyczące sposobów podejmowania decyzji odnośnie do jego funkcjonowania (np. wyboru reprezentanta), zgodne z postanowieniami uchwały rady wydanej na podstawie art. 41a ust. 5 u.s.g. Zasadne wydaje się również jasne uregulowanie uprawnień do wniesienia skargi do sądu administracyjnego na bezczynność rady oraz kwestii likwidacji komitetu.

Przeprowadzone badania nie rozstrzygaja, czy uzasadnione byłoby nadanie komitetom zdolności prawnej w zakresie prawa cywilnego. Poczynione ustalenia prowadzą jednak do wniosku, że warto ponownie przemyśleć ich koncepcję i jednoznacznie określić, czy mają one pełnić kluczową rolę w przedmiotowej procedurze, czy też może - jako podmiot zbędny - należałoby usunaćc tę instytucje. Wydaje się, że lepszym rozwiązaniem byłoby wzmocnienie ich roli jako ciał pośrednich między niektórymi mieszkańcami a organami gminy, co doprowadziłoby do lepszego zabezpieczenia interesów tych pierwszych (bez szkody dla interesów całej wspólnoty).

Banaszak, B. (2015). Art. 84, [w:] Kodeks wyborczy. Komentarz. Warszawa. SIP Legalis.

Banat, M. (2020). Obywatelska inicjatywa uchwałodawcza jako instytucjonalny środek kontroli społecznej w samorządzie terytorialnym. Samorząd Terytorialny 7/8: 79-94.

Czakowska, M., Raźny, P. (2011). Konstrukcja prawna komitetu wyborczego w kontekście zasady równych szans wyborczych. Studia BAS 3(27): 73-91.

Czerw, J. (2016). Citizens' initiative in the process of adopting resolutions by municipal councils. Przegląd Prawa Publicznego 7/8: 200-212.

Frąckowiak, J. (2012). Osoby prawne, [w:] M. Safjan (red.), System prawa prywatnego. Tom 1: Prawo cywilne - część ogólna. Warszawa. SIP Legalis.

Gajewski, S. (2018). Ustawy samorządowe. Nowe instytucje. Analiza z przykładami i wzorami dokumentów. Warszawa. SIP Legalis.

Giętkowski, R. (2010). W sprawie koncepcji prawa ustrojowego (uwagi na tle problematyki podziału systemu prawa na gałęzie). Gdańskie Studia Prawnicze 24: 129-138.

Górczyński, G. (2018). Art. 33, [w:] M. Fras, M. Habdas (red.), Kodeks cywilny. Komentarz. Tom 1: Część ogólna (art. 1-125). Warszawa. SIP Lex.

Grossmann, T., Piątek, W. (2016). Zdolność sądowa i procesowa stowarzyszenia zwykłego w postępowaniu sądowoadministracyjnym. Przegląd Prawa Publicznego 3: 77-95.

Izdebski, H. (2014). Glosa do wyroku WSA z 14 maja 2013 r., II SA/Ol 196/13. Samorząd Terytorialny 1/2: 163-168.

Kopaczyńska-Pieczniak, K. (2019). Korporacja. Elementy konstrukcji prawnej. Warszawa.

Kuśnierz-Chmiel, J. (2016). Inicjatywa uchwałodawcza mieszkańców województwa. Samorząd Terytorialny 1/2: 63-74.

Marchaj, R. (2018). Komentarz do art. 41a, [w:] B. Dolnicki (red.), Ustawa o samorządzie gminnym. Komentarz. Warszawa. SIP Lex.

Miruć, A. (2010). Obywatelska inicjatywa uchwałodawcza. Samorząd Terytorialny 1/2: 31-38.

Niczyporuk, J. (2018). Koncepcja organu administracji publicznej z perspektywy kodyfikacji, [w:] Z. Kmieciak, W. Chróścielewski (red.), Idea kodyfikacji w nauce prawa administracyjnego procesowego. Księga pamiątkowa Profesora Janusza Borkowskiego. Warszawa. 235-241. 
Niczyporuk, J. (2016). Podmiotowość administracyjnoprawna. Lublin.

Podgórska-Rykała, J. (2020). Obywatelska inicjatywa uchwałodawcza. Uwarunkowania praktyczne i prawne. Warszawa. SIP Legalis.

Sobolewski, P. (2017). Art. 33 T.I. KC, [w:] K. Osajda (red.), Tom 1: Kodeks cywilny. Komentarz. Część ogólna. Przepisy wprowadzające. Kodeks cywilny. Prawo o notariacie (art. 79-95 i 96-99). Warszawa. SIP Legalis.

Szczepaniak, R. (2016). Art. $33^{1}$ KC, [w:] M. Gutowski (red.), Kodeks cywilny. Tom 1: Komentarz. Art. $1-449^{11}$. Warszawa. SIP Legalis.

Uziębło, P.J. (2011). Glosa do wyroku WSA z dnia 28 października 2008 r., II SA/Ol 737/08. Gdańskie Studia Prawnicze - Przegląd Orzecznictwa 2: 56-62.

Zieliński, M. (2017). Wykładnia prawa. Zasady, reguły wskazówki. Warszawa.

Ziółkowski, D. (2018). Komentarz do art. 41a, [w:] S. Gajewski, A. Jakubowski (red.), Ustawa o samorządzie gminnym. Komentarz. Warszawa. SIP Legalis.

\section{THE COMMITTEE OF THE CITIZENS’ LEGISLATIVE INITIATIVE}

\section{Sum mary}

The 2018 amendment to local government laws introduced the institution of citizens' resolution committees into the legal system, closely related to the exercise of the rights of inhabitants. The regulations do not explicitly define the legal nature of these creations. Thanks to the analysis of the provisions, it is established that the committees can be considered as specific entities of administrative law with a limited scope of activity. They do not have subjectivity within the meaning of civil law.

Keywords: committee; resolution initiative; subject of administrative law; court capacity 
